\title{
Policies, Skills and Earnings: \\ How Educational Inequality Affects Earnings Inequality
}

\author{
Daniele Checchi $^{\text {a }}$ \\ University of Milan \\ Herman G. van de Werfhorst ${ }^{*}$ \\ University of Amsterdam \\ h.g.vandewerfhorst@uva.nl \\ ${ }^{*}$ corresponding author, ${ }^{\mathrm{a}}$ Equal contributions of both authors
}

Forthcoming in: Socio-Economic Review, 2017

\begin{abstract}
We study the impact of dispersions in education (both in student test scores and final educational attainment) on earnings inequality, in a country-cohort design. Neo-classical economic theory would predict a positive association between skill inequality (as measured in student test scores) and earnings inequality, while educational attainment inequality adds little on top of skills inequality. A sociological theory of social closure, however, argues that inequality in educational attainment is more important than skills inequality in the prediction of earnings inequality. Using educational policies as instruments, we find causal effects of skills inequality and educational attainment inequality, suggesting that a simple human capital model is insufficient to explain rising earnings inequalities. Nevertheless, skills inequality appeared a more important predictor of earnings inequality than educational attainment inequality. Some educational policy reforms (like public preschool provision or introducing standardised tests) led to reduced educational dispersions, and thereby reduced earnings inequality in adulthood.
\end{abstract}

Keywords: education, inequality, human capital, income distribution Jel codes: I24 Education and Inequality - I28 Government Policy 


\section{Introduction}

The relationship between educational distributions and labour market distributions has been at the core of economic and sociological research. Society gets increasingly stratified on the basis of education. Economic theories and structural-functionalist allies in sociology have explained the increased importance of education through increased complexity work and the resulting higher demand for higher-level skills. Theories of social closure argue that education is increasingly rewarded for other reasons than simply rising demand for skills; education has become a core mechanism to create and maintain boundaries between social groups.

Despite the huge attention for the school-work relationship, the literature has been primarily concerned with differences in average educational attainment and achievement and its relationship to the average probability to find a higher-class occupation, or earn higher salaries. Much less attention has been paid to dispersions in educational distributions, and how these relate to dispersions in labour market outcomes such as earnings. This means that dispersions in education and in the labour market have been analyzed mostly in isolation. This is unfortunate for both scientific and political reasons. From a scientific perspective, the divorced studies of educational and earnings inequalities fail to acknowledge that one potential explanation of earnings inequalities may be found in the unequal distribution of education and skills. While many studies have related the rising earnings inequalities to rising gaps among educational categories (e.g. Goldin and Katz 2009; Hout 2012), little research has directly examined the dispersion in earnings in relation to the dispersion in skills and qualification levels. Moreover, while most studies that examined the relationship between education and labour market outcomes focused on educational attainment (e.g. in terms of qualification levels of years of schooling attained), recent scholarship argues that the quality of education in terms of skill assessments is of greater importance for economic growth than the quantity of education in terms of average years of schooling completed (Hanushek and Woessmann 2008). It is important to examine the relevance of quality and quantity of education also from an inequality perspective. Different theoretical perspectives emphasize different aspects of education to be relevant for social stratification. Some theories emphasize the productivityenhancing skills that schooling provides, while others put more weight on the formal qualifications that provide access to desirable positions. To further scrutinize these different theoretical perspectives, it is important to apply them to inequality. It may help us not only to understand who gets ahead in the stratification order, but also how societal inequality is affected by inequalities in the various elements of education.

From this perspective it is important to know what is more important for the determination of earnings inequality: inequality in skills (student test scores) or inequality in educational 
attainment? We derive hypotheses from standard neo-classical economics and sociological closure theory, which differ in the importance that may be attached to either skills or educational attainment. Thus, examining both skills and attainment helps us to understand more about how mechanisms about returns to education have contributed to the rising inequality in earnings in many societies.

From a political perspective it is important to understand the relationships between educational and income inequalities because policies that are mainly oriented towards the manipulation of educational distributions can have wider repercussions on the social stratification in adult life. Furthermore, for political debates it is important to study the effectiveness of policies in affecting the dispersions in achievement, and/or in educational attainment.

We contribute to a better understanding of the associations between educational policies, educational distributions and earnings distributions by combining various datasets. We match comparative mathematics achievement data (as indicator of the 'quality' of education) with educational attainments (as a proxy for the 'quantity' of education), labour force participation and earnings in the adult population. The match exploits combinations of cohort, country and gender, and for each combination we have calculated educational and earnings inequality measures. We show that educational inequality (in terms of dispersion) is correlated with earnings inequality thirty years later, with 'quality' being more relevant that 'quantity' in shaping earnings inequality. Furthermore, to investigate the importance of educational policies, we have matched these population data (combining cohorts and countries) with data on educational policies, including policies on compulsory education, school and/or teachers' autonomy, and tracking age (from Braga et al. 2013). We employ instrumental variable models to validate that inequality in education (measured in terms of both quality and quantity) affects earnings inequality. In addition, since educational inequality responds to educational reforms, we are able to identify some educational policies (like later entry into compulsory education or the introduction of standardised tests) capable to reduce earnings inequalities once the same cohort is in the labour market.

As a replication exercise, we match data from a survey conducted in 2000 on 15-year old youngsters math test score with the corresponding cohort in the same country 12 years later. For both groups of individuals we show that inequality in skills accounts for a significant portion of observed earnings inequality.

\section{Theoretical background: Educational distributions and earnings distributions}

\section{Mechanisms linking education and labour market outcomes}


Education and labour market outcomes are well-known to be strongly correlated: those with more schooling and more advanced skill levels have higher earnings, higher occupational status, and preferable employment relations than those with less education. Education is therefore generally considered as one of the main determinants of the position people take in the social structure.

Studies often relate the rising earnings inequalities witnessed in many societies to rising returns to educational qualifications (although also within-group inequality has increased). According to functionalist sociological theory of modernization, and their allies from neo-classical economics, labour market outcomes are increasingly stratified on the basis of education because the labour market becomes more complex through technological developments, and rising demand for skills increases the price of labour (Bell 1974; Davis \& Moore 1945; Goldin \& Katz 2009). Although this model assumes that rising educational gradients correspond to a rising return on skills (due to increased productivity created by skill-biased technological change), empirical research typically examines earnings differences between qualification levels. But returns to qualification levels could also correspond to other mechanisms why education is rewarded. In particular, the sociological theory of social closure argues that qualifications are rewarded for reasons other than productivity-enhancing skills (Van de Werfhorst 2011; Di Stasio et al. 2016). Following Solga (2014) we therefore consider it relevant to study the relationship between educational distributions and income inequality from both the neo-classical/functionalist and closure perspectives.

The neo-classical/functionalist model assumes education is rewarded because of the skills that are associated to it. Within neo-classical economics, there are two arguments that call for a very strong relationship between skills and educational attainment. First, skills could be produced in the educational system, as standard human capital theory argues. Second, education sorts on skills that students already have before they go into schooling (Weiss 1995). Both perspectives hold that reward on the basis of education is efficient as education indicates the skills that people hold. The neo-classical model holds that sorting in education on the basis of ability is perfect, where further investments in education depend on expected returns and the ability students have to complete higher levels of schooling. So observing a person's skills should be highly informative of the human capital s/he commands.

The baseline argument of the closure perspective, by contrast, is that formal or informal rules are governing the placement of people in the stratification order. This perspective originates from a Weberian theory on stratification, which holds that advantaged groups search for ways to secure their advantage by norms and regulations (Brown 1995). Informal norms can, for instance, correspond to the cultural background of people of different qualification levels fitting different sorts of occupations. High-level occupations are allocated to graduates from tertiary education not only because they have skills to carry out the tasks, but also because they display affinity with the 
dominant cultural codes in society that is required to perform well in those functions (Bourdieu 1998; Rivera 2012). Formal regulations correspond to closure practices that govern the formal accessibility of occupations, like licensing and certification (Bol 2014; Weeden 2002). The supply of workers can then be controlled, creating rents in the form of earnings above the market value of skills. As a summary of the closure perspective, Brown (2001: 20) writes, "credential requirements for jobs are less concerned with concrete work skills than with demanding that recruits hold similar, school-taught cultural dispositions to incumbents of positions". Importantly, the closure perspective holds, just like the functionalist/neo-classical perspective, that education is increasingly rewarded in the labour market, but for different reasons.

In line with closure theory, neo-institutionalists furthermore argue that the societal change in relation to the 'schooled society' involves more than a simple school-to-work allocation process (Baker 2014; Meyer and Ramirez 2000). The institutionalization of education is partly based on a 'myth' concerning the relationship between educational attainment and individual marginal productivity (Schofer and Meyer 2005). Because institutionalization also implies a social construction of the value of education, an empirically demonstrable value of education can emerge because we all believe in the myth and organize society on this basis. The neo-classical economic model can be criticised from this perspective because educational earnings returns are both the outcome of study and the (faulty) mechanism of marginal productivity explaining it.

In order to differentiate between neo-classical and closure models of stratification, it is essential to incorporate separate measures of skills (as indicator of the quality of education) and educational attainment (as indicator of the quantity of education). Neo-classical economists show that skills explain a large fraction of why education is rewarded on the labour market (Blau and Kahn 2005; Leuven et al. 2004). Critics of the neo-classical model, however, have demonstrated that educational gradients in earnings are only marginally reduced when skills are taken into account (Bowles and Gintis 2002).

\section{Education inequality and earnings inequality}

The positive relationships between cognitive skills, educational attainment and earnings imply that earnings inequality can be partly attributed to dispersions in educational quality and quantity. Blau and Kahn (2005) claim that the greater dispersion of cognitive test scores in the United States plays a part in explaining higher U.S. wage inequality. Competences also provide an autonomous contribution to observed inequality, conditional on identical school attainment (Green and Riddell 2003). Freeman and Schettkat (2001) show that the U.S. are characterised by greater inequality in adult competences than Germany, which is reflected in greater inequality in earnings. Using a wider 
country coverage and the more recent PIAAC data, Solga (2014) confirmed a positive relation between inequality in adult competences and income inequality.

Some studies have linked student competences assessed during high school with income inequality. Bedard and Ferrall (2003) show a positive association between inequality in mathematics performance during high school and wage inequality in adulthood of the same birth cohorts. Moreover, the association was hardly affected by including trade union density as an indicator of (wage-compressing) wage centralization. Busemeyer (2015) examined skill inequality in terms of the slope by parental background, rather than in terms of dispersions. No statistical association was found between inequality of educational opportunity in PISA test scores among 15year-old students and income inequality taken from OECD data.

The two theoretical approaches summarized above have a different perspective on the relevance of competences and educational attainment. According to the neo-classical/functionalist model, educational attainment strongly overlaps with measured skills, so that inequality in skills should be more strongly predictive of the level of earnings inequality in adulthood than inequality in attained years of schooling (hypothesis 1). According to the closure theory, by contrast, the possession of skills is not sufficient to achieve high incomes. Skills are only useful to the extent that they have been 'translated' in attainment levels that are used to govern the allocation of workers to the occupational structure. Controlling for inequality in educational attainment, skills inequality should therefore be of minor importance for the explanation of earnings inequality in adulthood (hypothesis 2).

The two hypotheses follow from very strong versions of the neo-classical/functionalist and closure perspectives. In the strict version of the neo-classical/functionalist theory a person's human capital is assumed to perfectly overlap with his/her measured cognitive skills (due to reduced cost and/or increased productivity for abler individuals), and the strict version of the closure theory assumes that the only reason that qualification levels are rewarded (conditional on skills) is that informal and formal rules are used. Although these are strong assumptions, they help us to interpret the relative weight of skills inequality and educational attainment inequality. So, if skills inequality would be highly predictive of earnings inequality in adulthood, even after including attainment inequality in the empirical model, it is unlikely that closure theory is fully able to explain rising earnings inequalities in Western societies. Likewise, if attainment inequality is predominant in the explanation of earnings inequality, the least we can say is that the cognitive component of schooling' does not fully explain how educational inequality is associated to earnings inequality (see also Bowles and Gintis 2002 for a similar argument).

There is another justification for our rather stringent interpretation of these broad theoretical approaches. Rising earnings inequalities could be explained from a neo-classical educational 
perspective by either an increase of the price for the skills people have, or a change in the labour supply at different education levels. Both could work in the same, or in opposite directions (Goldin and Katz 2009). For instance, the price for skills may go up due to technological innovation (increasing education gaps), while the supply of higher levels of education also increases (counterbalancing this increase). However, it is plausible that people adjust their educational attainment in response to changing demand more easily than their level of skills. If technology grows, this may lead more easily to behavioural adjustments leading to higher participation rates in (tertiary) education than to higher skill levels. This could imply that the effect of skill inequality on earnings inequality more directly captures skill prices (largely unaffected by the conflation of supply), while the effect of educational attainment inequality also captures other, non-human capital returns to education. Educational attainment inequality may even reduce (because the dispersion in educational attainment reduces with expansion, Meschi and Scervini 2014) while the skill price (and earnings inequality) increases, leading to stronger effects of skill inequality on earnings inequality in the neo-classical model.

\section{Education policies and inequalities}

While a positive association is expected between educational and income distributions, it is worthwhile to be more explicit on how educational distributions are affected by education policies. Some of the cited studies have looked at education policies. Busemeyer (2015) for instance, showed that the size of the vocational education and training sector and public spending on higher education were negatively associated to the level of income inequality in a country (see also Busemeyer and Iversen 2012). However, that study has not examined the influence of policies on educational distributions, as one avenue through which income inequality might be affected.

Unlike previous studies, we approach educational policies as instruments of educational distributions, so we can estimate the causal effects of educational distributions on earnings inequality. Using educational policies as instruments is desirable because different policies can create different skill equilibria and earnings distributions (Iversen and Stephens 2008). As recent contributions to the Varieties of Capitalism field emphasize, educational policies can differ with regard to the stratification and de-commodification they create in the educational system, which results in varying levels of educational inequality (Busemeyer 2015). From a methodological perspective, instruments are desirable as there is potential endogeneity, since more talented individuals may possess higher level of competences (as well as achieve higher educational attainments) and obtain higher earnings. In the absence of credible instruments, it is hard to accept a causal interpretation of previous results. 
The impact of policies on educational distributions have been widely studied by now (Brunello and Checchi 2007; Hanushek and Woessmann 2011; Rindermann and Ceci 2009). Examples of policies that are associated to inequalities are the provision of pre-school education (Rindermann and Ceci 2009; Schütz et al. 2008; Heckman 2006), standardised testing (Horn 2009), tracking age (Bol et al. 2014), school accountability (Hanushek and Raymond 2004; Jennings and Sohn 2014) and the length of compulsory education (Leuven et al. 2010; Meschi and Scervini 2014). We focus on these same policies, which also enables us to study the indirect impact of these policies on earnings inequality.

Because we treat policies as instruments for educational distributions, we do not pay attention to other (labour market, welfare) policies that affect earnings inequality. Such policies are less important for the production of educational inequalities, unless one sees this from an intergenerational perspective (because welfare policies affect the economic resources of parents). Educational policies can also be endogenous to educational inequalities, since government can be induced to change the organisation of the educational system by observing increasing inequality in achievements and/or attainments. Braga et al. (2013) tested the exogeneity of educational reform measures by regressing current values of the reforms against past values of the inequality in schooling, finding no statistical association. They also showed that educational reforms correlate with the left-right inclination of governments, and provided IV estimation where variations in educational reforms (induced by electoral changes) caused changes in educational inequality. It should, however, be acknowledged that education policies can also be part of larger constellations of agreements between the state and employer and employee organizations, including labour market policies (Busemeyer 2015; Iversen and Soskice 2001). For our analysis this poses less of a problem, as we are not aiming to endogenize education policies, but educational distributions.

\section{Empirical strategy}

In the absence of cross-nationally comparative individual-level longitudinal data with school-age competences, schooling attainment and further labour market careers we pursue an alternative strategy of country/cohort analysis, matching aggregate inequality measures of competences, schooling and earnings based on the birth year of the relevant cohort. We use data for multiple cohorts born since 1950, observed at various ages.

By indicating with $I(x)$ a generic inequality indicator, we study the how the inequality in $y$ (earnings) will depend on the inequality in both quality $q$ (ability tests) and quantity $h$ (educational attainment).

$$
I\left(y_{j t}\right)=\delta_{j}+\delta_{t}+\alpha I\left(h_{j t}\right)+\beta I\left(q_{j t}\right)+\omega_{j t}
$$


where $\delta_{j}$ and $\delta_{t}$ are country/cohort/survey fixed effects capturing any other sort of systemic earnings inequality variation beyond education, while $\alpha$ and $\beta$ measure the association between (the distribution of) various dimensions of human capital (quantity and quality) and earnings inequality. If $h$ and/or $q$ are measured well in advance with respect to $y$ (in our case $h$ is measured at the end of schooling by the maximal educational attainment, $q$ is measured at the age of 14 or 15 , while $y$ is measured alternatively at the ages of 28,44 and 59), one is tempted to provide a causal interpretation of statements like "a reduction in inequality in test scores reduces income inequality by a magnitude $\beta$ ". However, unobservable components at country level (like competitiveness, solidarity, ethnic fractionalisation and so on) may drive both dimension of inequality, leading to biased estimates of the relevant coefficients. Accounting for this possibility, one can resort to an instrumental variable strategy to estimate equation (1) leading to

$$
\left\{\begin{array}{l}
I\left(h_{j t}\right)=a_{j}+a_{t}+\mathbf{b}_{j}^{\prime} \mathbf{Z}_{j t}+e_{j t} \\
I\left(q_{j t}\right)=c_{j}+c_{t}+\mathbf{d}_{j}^{\prime} \mathbf{Z}_{j t}+g_{j t} \\
I\left(y_{j t}\right)=\delta_{j}+\delta_{t}+\alpha \hat{I}\left(h_{j t}\right)+\beta \hat{I}\left(q_{j t}\right)+\omega_{j t}
\end{array}\right.
$$

where the educational inequality measures in equation (1) are replaced by their projections obtained from a vector of (supposedly) exogenous variables pertaining reforms in the educational sectors affecting the relevant birth cohorts. ${ }^{1}$ We thus exploit both geographical and temporal variations in educational reforms by government to obtain unbiased estimates of the causal impact of educational inequality on earnings inequality.

\section{Dataset 1: IMS-ECHP-SILC and educational reforms}

Data on students' competences are obtained from three early surveys on mathematical competences of (around) 14-year-old students conducted in past decades (FIMS 1964 was the First International Mathematics Study testing mathematical competences of students born in or around 1950; the Second (SIMS 1980-82) tested students born in or around 1966 and the Third (TIMSS 1995) tested students born in or around 1981, all assumed to be nationally representative). ${ }^{2}$ We thus start with a population composed by three birth cohorts, born in 1950, 1966 and 1981 respectively, in countries that participated to the student assessment surveys. Data on schooling and labour market outcomes for the same cohorts can be obtained from representative samples of the corresponding population at later stages. However, if observed at the same point in time, we would be confounding cohorts and age effects (namely, older cohorts may be characterised by higher (possibly lower, due to 
natural decay) level of competences and earnings inequalities). For this reason, we use two available datasets existing at European level and reporting data on earnings and incomes: the European Community Household Panel (ECHP), which started in $1994^{3}$, and the European Union Statistics on Income and Living Conditions (EU-SILC), which started in 2004 and is updated annually. ${ }^{4}$ We selected the 1994 ECHP wave because it was the earliest available, while we resorted to the 2009 SILC wave because it was the first survey reporting consistent information on gross incomes for all participating countries. In table 1 we show the matching rule we followed to construct our dataset. Take for example the students born in 1950 and tested in 1964 among others in six European countries (Belgium ${ }^{5}$, Finland, France, Germany, Netherlands and United Kingdom). The same birth cohort can be observed in the labour market around the age of 44 in 1994, thanks to ECHP (Finnish data not available, since Finland entered in 1996), and again at age 59, using the SILC data. The same logic applies to the other cohorts.

[Table 1 here]

Labour earnings data are obtained summing earnings from dependent employment and earnings from self-employment, and excluding cases of negative values. In the ECHP all values (except France) are net of taxes, while in the SILC we use gross values (this is one reason to add a survey fixed effect). Negative earnings values exist in the case of self-employed, they have been converted into zeros in order to allow the calculation of inequality. Individuals without earnings (housewives, unemployed, out of labour force) report zero values, but have been retained in our sample since labour market participation is potentially endogenous and definitely correlated with educational attainment and possession of competences.

Years of education have been computed from maximum educational attainment according to the ISCED classification converted into years by using legal duration. ${ }^{6}$ Mathematics test scores, the only domain that has been tested since the 1964 FIMS, are calculated for the FIMS, SIMS and TIMSS data based on the number of correct answers to multiple-choice items. ${ }^{7}$ In order to partially account for gender composition and increase the degrees of freedom, we have computed these inequality measures separately for males and females.

The country inequality measures (averaged over genders) are reported in table A1. Overall we possess an unbalanced panel covering 20 countries with 82 observations (41 country/cohort $\times 2$ genders). Figure 1 shows the plot of the relevant data for the 20 countries, while table 2 reports the descriptive statistics for the relevant variables. We can observe that there is a modest positive correlation ( 0.18$)$ between inequality in quantity and inequality in quality of education for the country/gender/cohort cell available (north-west panel). ${ }^{8}$ Inequality in the quality of education has a 
modest (but insignificant) correlation with earnings inequality (computed over employees - northeast panel), while there is no bivariate correlation between inequality in educational attainment and earnings inequality. In the last south-east panel we contrast earnings inequality for dependent employees and for total employment. The correlation among the two inequality measures is considerable (0.43).

[Table 2 here]

Potentially confounding factors are controlled by means of corresponding dummies (gender, birth year, age, country and survey). For gender this refers to the share in the data of men in the countrycohort-age group.

[Figure 1 here]

We do not have a priori about which is the most appropriate economic inequality measure to be used in this analysis, since each index captures different dimensions of the underlying distributions. We have decided to focus on the Gini index as our relevant measure of inequality, since it is the most commonly used measure for income inequality. Table 3 shows results with fixed effects, still without examining education policies. The table shows positive effects of inequalities in quantity and quality of human capital (see columns (1) and (2) of table 3). Clustering errors weakens the statistical significance of inequality in test scores (columns (3) and (4) of table 3).

If we restrict the analysis to individuals with positive earnings values, part of the effect of educational inequalities is absorbed by the sample selection (especially among women and older birth cohorts). As we see from columns (5) and (6) of table 3, both inequality in test scores and inequality in educational attainment (measured across individuals with positive earnings) lose magnitude. This is an indication that whenever we measure earnings inequality we face a huge problem of self-selection into the labour market, which we are unable to properly model in this context. For this reason, we stick to the solution of including all the relevant population, imputing zero earnings when they are out of the labour market. ${ }^{9}$

[Table 3 here]

Overall, the magnitude of the coefficient on inequality in test scores oscillates between 1 and 1.7, while the coefficient on inequality in years of education remains in the range of half of it, between 
0.5 and $0.8 .^{10}$ In terms of elasticities (measured at sample means), earnings inequality measured by Gini concentration indices would exhibit an elasticity of 0.61-0.69 with respect to inequality in test scores and 0.21-0.22 with respect to inequality in years of education (computed from columns (3) and (4) of table 3 ).

Table 4 presents the instrumental variable estimation. We use the measures of educational reforms constructed by Braga et al. (2013) covering various stages of schooling. If we exclude age of begin/end of compulsory education and age of first tracking, the majority of these reform measures are scale-free, because they count the number (and direction) of policy intervention. ${ }^{11}$ Table A2 in the Appendix presents the areas for which information is available, while figure A1 in the same Appendix plots the cross-country averages of these educational reform measures for one area of reform.

For ease of comparison in columns (1) and (2) of table 4 we have reproduced columns (3) and (4) of previous table 3. In columns (3) and (4) we present the corresponding IV estimations using a 2SLS estimator, while in columns (5) and (6) a GMM estimator is proposed (which allows for heteroskedasticity of the errors and is more convenient when the number of instruments largely exceed the number of supposedly endogenous variables). The bottom part of the table reports the first stage coefficients of the regression of the endogenous variables onto the instruments represented by measured reforms. Starting with first stage coefficients signs and significance, we notice that inequality in years of education is reduced in countries that expanded pre-primary education or postponed the beginning age for compulsory education, while the school leaving age seems to have a counterintuitive positive correlation. Postponing the age at which students have to choose the secondary school track (wherever the educational system is stratified, like in Austria, Germany, Italy and the Netherlands) seem to increase both inequalities in schooling and test scores. ${ }^{12}$ On the contrary, strengthening the standardisation of national educational systems through the introduction of student testing is associated to a reduction of inequality. Finally, consistent with the results of Braga et al. (2013), increasing schools/teachers and universities autonomy reinforce their potential competitiveness, at the expenses of increased educational inequality. Similar patterns are observed in the case of competence inequality. The statistical significance of these effects relies on the method utilised to estimate the variance-covariance matrix: while educational reforms remain significant for test score inequality under both IV estimators, they tend to lose significance in the case of attainment inequality when passing to GMM method of estimation. ${ }^{13}$ Using the predicted inequalities in quantity and quality of education as regressors for earnings inequality, we observe that their coefficients lose statistical significance in comparison with OLS, while rising in magnitude in the case of schooling inequality. As long as educational reforms are reasonable exogenous instruments (which is formally tested as robustness check in Braga et al. 2013), these 
values can be interpreted as causal impacts. ${ }^{14}$ Looking at column (6), we may say that OLS estimates for test score inequality were upward biased, while the opposite situation occurs for schooling inequality, which now becomes more relevant. In terms of elasticities, the two dimensions of educational inequalities get closer $(0.57$ for test score inequality and 0.36 for schooling inequality, both computed from column (6) of table 4 at sample means).

[Table 4 here]

Table 5 summarises the policy implications which can be inferred by the use of instrumental variables. This is done in two ways, by directly estimating a reduced form (where $I(y)$ is directly regressed onto the reform variables vector $\mathbf{Z}$ ) and by computing the overall impact of educational reforms onto earnings inequalities. ${ }^{15}$ Most of these effects are consistent with the previous literature: reinforcing early (pre)schooling, delaying the beginning age for compulsory education, reinforcing educational standardisation by introducing standardised test scores, all reforms yield a reduction in earnings inequalities observed many years later in the labour market. On the contrary, increasing teachers' autonomy (in the selection of teaching contents), reinforcing school accountability and/or boosting university autonomy widen earnings differentials. According to the reduced form estimation, two additional reforms (increasing the years of education and delaying the tracking) come out statistically insignificant with respect to earnings inequalities.

[Table 5 here]

In order to visualise the magnitude of these impacts, in figure 2 we have plotted the reduced form coefficients (column 1 of table 5) multiplied by one standard deviation change of the reform variables. The units of the horizontal axis of figure 2 are to be interpreted as Gini points. Results are strongly consistent with the findings of Braga et al. (2013): some reforms are effective in reducing earnings inequality, in particular the expansion of public pre-primary education. Braga et al. (2013) call these "inclusive" policies, while Busemeyer (2015) uses a slightly different conceptualization of de-commodification. Other reforms are effective in raising earnings inequality, via increased variability in both dimensions of human capital in the relevant population. These policies are "selective" because they increase the degree of competition among educational institutions (Braga et al. 2013); while in Busemeyer's (2015) approach these policies would be a mixture of commodified (marketised) and stratified policies. Results are almost identical when considering total earnings. 
[Figure 2 here]

Overall, our results do not reject our hypothesis that inequality in education affects inequality in earnings along two dimensions, quality and quantity. In addition, we have also shown that inequality in quality (as measured by student test scores) and inequality in quantity (as measured by years of schooling) respond to educational policies.

\section{Dataset 2: PISA-PIAAC}

One may suspect that previous results are driven by confounding factors, not properly accounted by country/year fixed effects, since we are considering quite different birth cohorts. In order to check the consistency of previous results with respect more homogenous populations, we have performed a different exercise on more recent surveys. We consider an adult population to which we impute competences measured when they were young, showing first that their current earnings are (weakly) correlated to past (and current) competences, and second that inequality in current earnings is correlated to either past or current inequality in competences, as in the previous exercise. In practice, we have taken the first PISA survey conducted in 2000 on 15-year-old students. ${ }^{16}$ These students are aged 27 in 2012 when another survey on the adult population (aged between 16 and 65) was conducted. ${ }^{17}$ The latter survey contains information on earnings, schooling and level of competences measured at the time of the survey. Thanks to the background information available in both surveys (gender, foreign born, highest parental education, books at home), ${ }^{18}$ we can identify 48 "types" in each of the 20 countries taking part to both surveys (numbers of individual in each surveys are reported in table A3). When looking at the distribution of the background information in the two surveys (see table 6) we notice that the foreign born population share has increased between the two surveys, while parental education and books at home tend to be similarly distributed.

[Table 6 here]

We impute the PISA test results by type to the individual-level PIAAC data. Imputed mean competences are obviously correlated with currently measured proficiency $(0.46)$, which in turn is also correlated with schooling and labour market participation. ${ }^{19}$ In table 7 we present two groups of estimates according to the dependent variable which is available: for a subset of 15 countries the hourly wage is available as a continuous variable; for the largest set of 20 countries the earnings is only available in decile. As a consequence, columns 1 to 3 of table 7 presents OLS estimates, while 
columns 4 to 6 utilises an order probit estimator: the coefficients are therefore only comparable in terms of sign and significance, but not of size.

[Table 7 here]

The first model considers quantity (years of schooling) ${ }^{20}$ and contemporaneous quality (proxied by numeracy test score, computed as mean of ten plausible values) of education: both are positively correlated to earnings, but the former dominates in terms of magnitude. In the restricted dataset of 15 countries, we find that the average PISA score of a person's type is not significantly correlated to average earnings in adulthood. Models 4-6, covering 20 countries, show that adult competences, high-school competences and years of education all are directly and significantly associated to earnings.

[Figure 3 here]

The various inequality measures are presented in figure 3 . The strongest correlation is between inequality in schooling and inequality in current competences (south-west quadrant), because the latter are clearly cumulated following the permanence in school. However current competences are also correlated with competences when in school (north-west quadrant). But we have to remind that inequality in competences when young is an underestimate of actual inequality (since in the current exercise it comprises only the between-group component). This may explain its low correlation with schooling (south-west quadrant). The raw data do not present (unconditional) correlation between inequality in achievements and inequality in earnings (south-east quadrant).

Moving to the replication of the inequality model, the estimates referred to the largest dataset are reported in table 8 . Column 1 of table 8 regresses the inequality on earnings (computed over relevant deciles for 20 countries) onto inequality of schooling and inequality in current competences for the relevant age cohort (25-29 year old); column 4 replicates the same structure extending the sample to a larger age cohort. In both cases inequality of current competences has a higher correlation with earnings inequality. However, if we replace current with (imputed) past competences (columns 2 and 5), the correlation becomes insignificant for the younger cohort, while it retains significance and magnitude for the largest sample. ${ }^{21}$ Finally we include both measures of quality of education (past and current competences) in addition to quantity of education in columns 3 and 6, but the effect of current competences dominates over the effect of past ones, which does not come out significant. So, while the earlier analysis pointed to stronger effects of skills inequality than of attainment inequality, the present analysis shows that contemporary skills 
inequality is more strongly associated to earnings inequality than skills inequality during the high school years. Yet, the fact that (adult) competences are more predictive of earnings inequality than attainment inequality confirms our findings on multiple cohorts.

[Table 8 here]

\section{Conclusions and discussion}

We studied the relationship between educational inequality and earnings inequality. Adopting a framework in which educational distributions have both a qualitative and a quantitative dimension, with quality referring to student performance on standardised tests, and quantity referring to the attained level of education, we perform two exercises where we examine the correlation existing in the available data using two alternative strategies of matching different datasets. In both exercises we find that inequality in quality of education affects inequality in earnings, even controlling for inequality in quantity (proxied by schooling). And the effect of quality is stronger than the effect of attained level. We employed instrumental variable models using information on educational reforms. Exploiting cross-country and cross-year variations in the policies, we are able to show that educational reforms have an effect on the distribution of the quality and the quantity of education.

Interpreting these results from different theoretical perspectives concerning how educational distributions are related to changing earnings inequalities, our findings are more consistent with a human capital/functionalist explanation than with an explanation derived from closure theory. Based on the alliance between human capital and functionalist theories, that hold that education is increasingly rewarded because of the skills that are needed in today's economies, a stronger effect of skill inequality is expected (as we found). Closure theory would hold that earnings inequality can only be explained by educational factors to the extent that educational performance is translated in educational attainment. Skills inequality should have a minor role once educational attainment inequality is held constant (opposite to what we found). Nevertheless, also educational attainment inequality had an independent effect on earnings inequality, which does support the claim that the contribution of education to explaining earnings inequality is not restricted to a human capital/functionalist model. In line with closure theory, educational attainment inequality has an independent effect on earnings inequality in most of our models.

One issue that we have not explicitly dealt with, but is potentially important for our findings, is within-group inequality. It is well-known that the rising earnings inequality cannot fully be attributed to rising inequalities between educational categories (supported in our analyses), because also within-group inequality is rising. If the within-education-group inequality is strongly 
overlapping with measured skills, then this could explain why we find stronger skill effects (which would still be consistent with our interpretation of the neo-classical/functionalist model). ${ }^{22}$

Note that the human capital/functionalist perspective fares better to explain associations between inequalities, but this does not mean that human capital theory also fares better to explain average earnings. Our analysis showed that educational attainment is strongly correlated with average earnings even after holding constant on (adult) competences. Following the approach by Bowles and Gintis (2002) this would point to relatively weak evidence for a human capital interpretation of how mean earnings are determined.

In line with earlier studies (Bedard and Ferrall 2003; Solga 2014), our results demonstrated that dispersions in educational outcomes are associated to dispersions in incomes. This central finding has important policy implications. Even if income policies have started to include an orientation towards education, our results more explicitly call attention for educational distributions as a cause of income inequality. While governments are increasingly concerned with students' performance in international tests, these concerns are mostly motivated by an efficiency concern of promoting economic growth. Our results would suggest that policy makers who are concerned about the growing income inequality in most Western societies should more explicitly incorporate educational distributions into their agenda setting. Education policy and income policy go hand in hand. Our approach has however limitations, since we cannot consider life-cycle implications of changes in current distributons of educational inequality. Due to the lack of longitudinal data we are unable to assess whether measured inequality in current earnings will expand or contract with years. Given existing evidence on the differential decay of competences by educational attainment, we suspect that inequality in earnings may increase overtime. But this is topic for future research.

\section{References}

Baker, D. (2014) The Schooled Society: The Educational Transformation of Global Culture. Stanford University Press.

Bedard, K. and Ferrall C. (2003) Wage and test score dispersion: some international evidence. Economics of Education Review 22: 31-43

Bell, D. (1974) The Coming of Post-Industrial Society: A Venture in Social Forecasting. London: Heinemann Educational.

Blau, F. and Kahn, L. (2005) Do cognitive test scores explain higher US wage inequality. Review of Economics and Statistics, 87(1): 184-193.

Bol, T. (2014) "Economic Returns to Occupational Closure in the German Skilled Trades." Social Science Research 46:9-22.

Bol, T. and Weeden, K.A. (2015) "Occupational Closure and Wage Inequality in Germany and the United Kingdom." European Sociological Review 31(3):354-69.

Bol, T., Witschge, J., Van de Werfhorst, H.G. and Dronkers, J. (2014) "Curricular Tracking and Central Examinations: Counterbalancing the Impact of Social Background on Student Achievement in 36 Countries." Social Forces 92(4):1545-72. 
Bourdieu, P. (1998) The State Nobility: Elite Schools in the Field of Power. Stanford University Press.

Bowles, S. and Gintis, H. (2002) "Schooling in Capitalist America Revisited." Sociology of Education 75(1):1-18.

Braga, M., Checchi, D. and Meschi, E. (2013) "Educational Policies in a Long-Run Perspective." Economic Policy 28(73):45-100.

Brown, D.K. (1995) Degrees of Control. A Sociology of Educational Expansion and Occupational Credentialism. New York: Teachers College Press.

Brown, D.K. (2001) "The Social Sources of Educational Credentialism: Status Cultures, Labor Markets, and Organizations." Sociology of Education 74:19-34.

Brunello, G. and Checchi, D. (2007) "Does School Tracking Affect Equality of Opportunity? New International Evidence." Economic Policy 22(52):781-861.

Busemeyer, M.R. (2015) Skills and Inequality: Partisan Politics and the Political Economy of Education Reforms in Western Welfare States. Cambridge University Press.

Busemeyer, M.R. and Iversen, T. (2012) "Collective Skill Systems, Wage Bargaining, and Labor Market Stratification.” Pp. 205-33 in The Political Economy of Collective Skill Formation, edited by M. R. Busemeyer and C. Trampusch. OUP Oxford.

Davis, K. and Moore, W.E. (1945) "Some Principles of Stratification." American Sociological Review 10(2):242-49.

Di Stasio, V., Bol, T. and Van de Werfhorst, H.G. (2016) "What Makes Education Positional? Institutions, Overeducation and the Competition for Jobs." Research in Social Stratification and Mobility, 43: 53-63.

Freeman, R. and Schettkat, R. (2001) Skill Compression, Wage Differentials and Employment: Germany vs. the US. Oxford Economic Papers, 53:3, pages 582-603..

Goldin, C.D., and Katz, L.F. (2009) The Race between Education and Technology. Harvard University Press.

Green, D. and Riddell, W. (2003) Literacy and earnings: an investigation of the interaction of cognitive and unobserved skills in earnings generation. Labour Economics 100(2): 165-84.

Hanushek, E.A. and Raymond, M.E. (2004) "The Effect of School Accountability Systems on the Level and Distribution of Student Achievement." Journal of the European Economic Association 2(2-3):406-15.

Hanushek, E.A. and Woessmann, L. (2008). The Role of Cognitive Skills in Economic Development. Journal of Economic Literature 46(3):607-68.

Hanushek, E.A., and Woessmann, L. (2011). The Economics of International Differences in Educational Achievement. In E. A. Hanushek, S. Machin, and L. Woessmann (eds.), Handbooks of the Economics of Education (Vol. 3, pp. 89-200). The Netherlands: NorthHolland/Elsevier.

Hanushek, E.A., and Woessmann, L. (2005) 'Does Educational Tracking Affect Performance and Inequality? Differences-in-Differences Evidence Across Countries’, Economic Journal 116: C63-C76.

Heckman, J.J. (2006) "Skill Formation and the Economics of Investing in Disadvantaged Children." Science 312(5782):1900-1902.

Heisig, J.P. and Solga, H. (2015) "Secondary Education Systems and the General Skills of Lessand Intermediate-Educated Adults A Comparison of 18 Countries." Sociology of Education 88(3):202-25.

Horn, D. (2009) "Age of Selection Counts: A Cross-Country Analysis of Educational Institutions." Educational Research and Evaluation 15(4):343-66.

Hout, M. (2012) "Social and Economic Returns to College Education in the United States." Annual Review of Sociology 38(1):379-400.

Iversen, T. and Soskice, D. (2001) "An Asset Theory of Social Policy Preferences." The American Political Science Review 95(4):875-93. 
Iversen, T. and Stephens, J.D. (2008) "Partisan Politics, the Welfare State, and Three Worlds of Human Capital Formation." Comparative Political Studies 41(4-5):600-637.

Jennings, J. and Sohn H. (2014) "Measure for Measure How Proficiency-Based Accountability Systems Affect Inequality in Academic Achievement." Sociology of Education 87(2):12541.

Leuven, E., Oosterbeek, H. and Van Ophem, H. (2004) "Explaining International Differences in Male Skill Wage Differentials by Differences in Demand and Supply of Skill." The Economic Journal 114(495):466-86.

Leuven, E., Lindahl, M. Oosterbeek, H. and Webbink, D. (2010) "Expanding Schooling Opportunities for 4-Year-Olds." Economics of Education Review 29(3):319-28.

Meschi, E. and Scervini F. (2014) "Expansion of Schooling and Educational Inequality in Europe: The Educational Kuznets Curve Revisited." Oxford Economic Papers 66(3):660-80.

Meyer, J.W. and Ramirez, F.O. (2000) “The World Institutionalization of Education.” Pp. 111-32 in Discourse Formation in Comparative Education, edited by J. Schriewer. Frankfurt: Peter Lang Publishers.

Rindermann, H. and Ceci, S.J. (2009) "Educational Policy and Country Outcomes in International Cognitive Competence Studies.” Perspectives on Psychological Science 4(6):551-68.

Rivera, L.A. (2012). "Hiring as Cultural Matching The Case of Elite Professional Service Firms." American Sociological Review 77(6):999-1022.

Schofer, E. and Meyer, J.W. (2005) "The Worldwide Expansion of Higher Education in the Twentieth Century." American Sociological Review 70(6):898-920.

Schütz, G., Ursprung, H.W . and Woessmann, L. (2008) "Education Policy and Equality of Opportunity." Kyklos 61(2):279-308.

Solga, H. (2014). Education, economic inequality and the promises of the social investment state. Socio-Economic Review, 12(2), 269-297.

Van de Werfhorst, H.G. (2011) "Skills, Positional Good or Social Closure? The Role of Education across Structural-institutional Labour Market Settings." Journal of Education and Work 24(5):521-48.

Weeden, K.A. (2002) "Why Do Some Occupations Pay More than Others? Social Closure and Earnings Inequality in the United States." American Journal of Sociology 108(1):55-101.

Weiss, A. (1995) "Human Capital vs. Signalling Explanations of Wages." Journal of Economic Perspectives 9(4):133-54.

${ }^{1}$ It is common procedure when there is more than one suspected endogenous variable to regress them on all exogenous variables and all instruments, since there is no statistical test indicating which instrument is more appropriate for which variable. In principle we could have selected some instruments as more theoretically appropriate for either inequality in skills or in education, but we would have not been able to reject alternative models.

${ }^{2}$ The micro-data on the second and third surveys (the first one is only publicly accessible on paper) are accessible through the International Association for the Evaluation of Educational Achievement, IEA, at www.iea.nl.

${ }^{3} \mathrm{http} / / /$ epp.eurostat.ec.europa.eu/portal/page/portal/microdata/echp.

${ }^{4}$ http://epp.eurostat.ec.europa.eu/portal/page/portal/microdata/eu_silc

${ }^{5}$ Belgian data are available for the Francophone and Flemish communities separately, but the same does not apply in the case of earnings data, therefore we were forced to consider Belgium as a unique entity.

${ }^{6}$ In order to account for potential country differences in retention rates, we faced the problem of attributing a standard duration (in years) of the maximal educational attainment. We have obtained an estimate of median duration of studies by using the individual age of leaving school (variable AGEDU in ECHP or variable PE030 "Year when highest level of education was attained" in SILC), 
and then we have assigned 7 years for ISCED $=1,10$ years for ISCED $=2,13$ years for ISCED $=3,15$ years for ISCED $=4$ and 18 years for ISCED $=5$ in SILC. Corresponding values are 8 for EDU $=1,12$ for $\mathrm{EDU}=2$ and 17 for $\mathrm{EDU}=3$ in $\mathrm{ECHP}$.

${ }^{7}$ Although since 1995, item response theory has been used to measure five plausible values of the true mathematics performance, for the earlier cohorts this was not possible. In TIMSS 1995 the correlation between our test score and the five plausible values is, in all five cases, 0.89 . For reasons of comparability we chose to operationalize math in the same way for all three cohorts.

8 One may notice that the inequality in years of education has lower values than inequality in test scores. This may partly be attributed to the fact that education is computed on a group-aggregate variable (standard duration for educational attainment) while test score is computed on a (bounded) continuous variable. Thus our inequality measure on quantity has lower mean and variance (corresponding to the between-group component) than the inequality measure on quality; other things constant the former should obtain a higher regression coefficient than the latter when correlated to inequality in earnings.

${ }^{9}$ As further robustness check we estimated our model separately for men and women, retaining some statistical significance for inequality in years of education, but losing it for inequality in tests score. But the relaiability of this check is limited, since country/cohort/survey fixed effects use 27 out of 41 degrees of freedom.

${ }^{10}$ This is only partially related with the different scales of measurement of inequalities in quantity and quality of human capital. If we were to replace the coefficients of column 5 in table 3 with beta coefficients (i.e. standardizing each variable), we would obtain a coefficient of 0.55 for inequality in quality and 0.27 for inequality in quantity.

${ }^{11} \mathrm{We}$ can look at the sign and the statistical significance of the estimated correlation between inequality in education and educational reforms, whereas when considering the magnitude we should distinguish according to whether we are dealing with step-dummies or continuous variables

${ }^{12}$ This latter effect contradicts standard findings in the literature on determinants of test scores (see for example Hanushek and Woessmann 2005) while it is consistent with the findings for inequality in years of education (Brunello and Checchi 2007).

${ }^{13}$ Notice that all regressions control for country, birth year, age and survey fixed effects, so that reform impacts are identified by time variation within the countries and/or gender differential impacts within each country/year.

${ }^{14}$ While we included all policies as instruments for both educational variables, one could also partition the policies as instruments for either test score inequality or attainment inequality. As a robustness check we did this, with public pre-primary, standardized tests, school accountability and teacher autonomy as instruments for math test inequality, and the other reforms as instruments for attainment inequality. The results (available upon request) showed significant positive effects of test score inequality, and non-significant positive effects of attainment inequality, just like in the 2SLS and IV GMM models of table 4. The effect sizes are larger, but that follows from the use of fewer instruments. As the choice of instruments for either one of the two educational variables is arbitrary, we chose to report the full instrumental variable models.

${ }^{15}$ We have multiplied the first stage coefficients - from bottom part of table 4 - by the impact of the supposedly endogenous variable - from upper part of table 4. Take for example a unitary increase of the variable "reform on public pre-primary schooling": it produces a decrease of skill inequality by -0.102 and education inequality by -0.096 . The overall decline in dependent employment earnings is the given by $[-0.102 \times 1.519-0.096 \times 0.730]=-0.225$. The effect on total labour earnings is computed in a similar way.

${ }^{16}$ See www.oecd.org/pisa/.

17 The PIAAC, see http://www.oecd.org/site/piaac/

${ }^{18} \mathrm{We}$ cannot use the exact age because 5 countries in PIAAC report age in 5-year brackets. Another information we would have liked to use for a coarser match would have been the type of secondary school attended, which is available in PIAAC but in PISA is only available starting from 2003. 
Thus we are left with gender $(2) \times$ native/foreign born $(2) \times$ highest parental education (recoded in 3 items for comparability across surveys - this now corresponds to the ECHP classification, indicated in footnote 6 ) $\times$ books at home (recoded in 4 items for comparability across surveys), yielding an overall number of 48 possible combinations, which are obviously unevenly distributed in the population.

${ }^{19}$ In analogy to the previous exercise, the lack of a proper longitudinal structure of the data forces us to consider only between-type inequality in test score of the young population (PISA), because we do not have a convincing strategy to reconstruct the within-type inequality of young test score in the adult population. It is therefore not surprising the correlation between young and adult test scores takes such a low value, since it is just measuring the between-type component.

${ }^{20}$ This variable is absent for Germany, and has been reconstructed from (median) leaving school age.

${ }^{21}$ Since inequality in test score captures inequality between-types, if there have been relevant compositional changes in the distribution of types across age-cohorts within each country (the average being cleaned away by the country fixed effect), this may be reflected in the statistical significance of inequality of competences at the younger age.

${ }^{22}$ However, dealing with within- and between-group inequality would require a different research design in which educational attainment, skills and luck are included in a structural model. 
Table 1: Construction of the sample-matching rule

\begin{tabular}{|c|c|c|c|c|c|}
\hline $\begin{array}{l}\text { Birth } \\
\text { year }\end{array}$ & Aged 14 & Aged 28 & Aged 43-44 & Aged 59 & $\begin{array}{c}\text { matched } \\
\text { cohorts/countries } \\
\end{array}$ \\
\hline $\begin{array}{c}195 \\
0\end{array}$ & $\begin{array}{l}1964 \text { (from FIMS: } \\
\text { BE,FI,FR,DE,NL,UK) }\end{array}$ & $\begin{array}{c}1978 \\
\text { (data not available) }\end{array}$ & $\begin{array}{c}1994 \\
\text { (from ECHP1994: } \\
\text { BE,FR,DE,NL,UK) }\end{array}$ & $\begin{array}{c}2009 \\
\text { (from SILC2009: } \\
\text { BE,FI,FR,DE,NL,UK) }\end{array}$ & 11 \\
\hline $\begin{array}{c}196 \\
6\end{array}$ & $\begin{array}{c}1980 \text { (from SIMS: } \\
(\mathrm{BE}, \mathrm{FI}, \mathrm{FR}, \mathrm{HU}, \mathrm{NL}, \mathrm{SE}, \mathrm{UK})\end{array}$ & $\begin{array}{c}1994 \\
\text { (from ECHP1994: } \\
\text { BE,FR,NL,UK) }\end{array}$ & $\begin{array}{c}2009 \\
\text { (from SILC2009: } \\
B E \\
\text { FI,FR,HU,NL,SE,UK) }\end{array}$ & & 11 \\
\hline $\begin{array}{c}198 \\
1\end{array}$ & $\begin{array}{r}1995 \text { (from TIMS: } \\
\text { AT,BE,CZ,DK,FR,DE, } \\
\text { GR,HU,IE,IT,LV,NL,NO, } \\
\text { PT,SK,SI,ES,SE,UK) }\end{array}$ & $\begin{array}{c}2009 \\
\text { (from SILC2009: } \\
\text { AT,BE,CZ,DK,FR,DE, } \\
\text { GR,HU,IE,IT,LV,NL,NO, } \\
\text { PT,SK,SI,ES,SE,UK) }\end{array}$ & & & 19 \\
\hline
\end{tabular}


Table 2: Descriptive statistics

\begin{tabular}{|l|c|c|c|c|c|}
\hline Variable & Obs & Mean & $\begin{array}{c}\text { Std. } \\
\text { Dev. }\end{array}$ & Min & Max \\
\hline $\begin{array}{l}\text { Gini index on dependent employment gross earnings } \\
\text { (including non labour force with zero earnings) }\end{array}$ & 82 & 0.466 & 0.110 & 0.254 & 0.721 \\
\hline $\begin{array}{l}\text { Gini index on gross earnings } \\
\text { (including self-employed and non labour force - negative earnings set to 0) }\end{array}$ & 82 & 0.433 & 0.109 & 0.229 & 0.698 \\
\hline $\begin{array}{l}\text { Gini index on years of education } \\
\text { (computed from ISCED attainments) }\end{array}$ & 82 & 0.120 & 0.032 & 0.072 & 0.243 \\
\hline $\begin{array}{l}\text { Gini index on dependent employment gross earnings } \\
\text { (only positive values - excluding unemployed with zero earnings) }\end{array}$ & 82 & 0.310 & 0.061 & 0.193 & 0.452 \\
\hline $\begin{array}{l}\text { Gini index on gross earnings } \\
\text { (including self-employed but excluding non labour force - negative earnings set to 0) }\end{array}$ & 82 & 0.316 & 0.061 & 0.209 & 0.472 \\
\hline $\begin{array}{l}\text { Gini index on years of education } \\
\text { (computed from ISCED attainments - only population with positive earnings) }\end{array}$ & 82 & 0.115 & 0.029 & 0.074 & 0.216 \\
\hline Gini index on math test scores & 82 & 0.175 & 0.031 & 0.124 & 0.244 \\
\hline age of individuals (when interviewed about occupational status) & 82 & 37.04 & 11.40 & 28 & 59 \\
\hline reform on public pre-primary schooling & 82 & 0.508 & 0.445 & 0 & 1 \\
\hline compulsory education (start age) & 82 & 6.024 & 0.608 & 5 & 7 \\
\hline compulsory education (end age) & 82 & 15.415 & 1.440 & 12 & 18 \\
\hline tracking age & 82 & 13.476 & 2.263 & 10 & 16 \\
\hline introduction of standardised test & 82 & 0.341 & 0.451 & 0 & 1 \\
\hline reform on school accountability & 82 & 0.293 & 0.458 & 0 & 1 \\
\hline reform on school teacher autonomy & 82 & 0.549 & 0.494 & 0 & 1 \\
\hline reform of university access & 82 & 0.606 & 0.430 & 0 & 1 \\
\hline
\end{tabular}


Table 3: Gross earnings and educational inequality - Gini indices - OLS with country fixed effects

\begin{tabular}{|c|c|c|c|c|c|c|}
\hline & $\begin{array}{c}1 \\
\text { dep.empl. } \\
\text { earnings } \\
\text { robust se }\end{array}$ & $\begin{array}{c}2 \\
\text { total } \\
\text { earnings } \\
\text { robust se }\end{array}$ & $\begin{array}{c}3 \\
\text { dep.empl. } \\
\text { earnings } \\
\text { clustered se }\end{array}$ & $\begin{array}{c}4 \\
\text { total } \\
\text { earnings } \\
\text { clustered se }\end{array}$ & $\begin{array}{c}5 \\
\text { dep.empl. } \\
\text { earnings >0 } \\
\text { clustered se }\end{array}$ & $\begin{array}{c}6 \\
\text { total } \\
\text { earnings }>0 \\
\text { clustered se }\end{array}$ \\
\hline inequality in math test scores & $\begin{array}{c}1.631 \\
{[0.555]^{\star * *}}\end{array}$ & $\begin{array}{c}1.716 \\
{[0.546]^{\star * *}}\end{array}$ & $\begin{array}{c}1.631 \\
{[0.815]^{*}}\end{array}$ & $\begin{array}{c}1.716 \\
{[0.817]^{\star *}}\end{array}$ & $\begin{array}{c}1.084 \\
{[0.508]^{\star *}}\end{array}$ & $\begin{array}{c}1.079 \\
{[0.560]^{*}}\end{array}$ \\
\hline inequality in years of $\mathrm{e}$ & 0.849 & 0.825 & 0.849 & 0.825 & 0.570 & 0.519 \\
\hline (from isced attainments) & {$[0.371]^{\star *}$} & {$[0.354]^{* *}$} & {$[0.370]^{\star *}$} & {$[0.377]^{\star \star}$} & {$[0.153]^{\star * *}$} & {$[0.194]^{* *}$} \\
\hline male component & $\begin{array}{c}-0.076 \\
{[0.012]^{\star * *}}\end{array}$ & $\begin{array}{c}-0.103 \\
{[0.012]^{\star * \star}}\end{array}$ & $\begin{array}{c}-0.076 \\
{[0.013]^{\star * *}}\end{array}$ & $\begin{array}{c}-0.103 \\
{[0.012]^{\star * *}}\end{array}$ & $\begin{array}{c}-0.037 \\
{[0.009]^{\star * *}}\end{array}$ & $\begin{array}{c}-0.033 \\
{[0.010]^{\star * *}}\end{array}$ \\
\hline Observation & 82 & 82 & 82 & 82 & 82 & 82 \\
\hline R-squared & 0.84 & 0.85 & 0.84 & 0.85 & 0.77 & 0.74 \\
\hline
\end{tabular}

col.1-2: robust standard errors in brackets - col.3-6: standard errors in brackets clustered by country - constant, country, age, birth year and survey controls included - * significant at $10 \%$; * significant at $5 \%$; ${ }^{* *}$ significant at 
Table 4: Gross earnings and educational inequality - Gini indices - OLS and IV estimates with educational reforms as instruments

\begin{tabular}{|c|c|c|c|c|c|c|}
\hline & 1 & 2 & \multicolumn{2}{|c|}{${ }^{3}$ IV 2SLS ${ }^{4}$} & \multicolumn{2}{|c|}{5 IV GMM 6} \\
\hline & $\begin{array}{l}\text { dep.empl. } \\
\text { earnings }\end{array}$ & $\begin{array}{c}\text { total } \\
\text { earnings }\end{array}$ & $\begin{array}{l}\text { dep.empl. } \\
\text { earnings }\end{array}$ & $\begin{array}{c}\text { total } \\
\text { earnings }\end{array}$ & $\begin{array}{l}\text { dep.empl. } \\
\text { earnings }\end{array}$ & $\begin{array}{c}\text { total } \\
\text { earnings }\end{array}$ \\
\hline $\begin{array}{l}\text { inequality in math test scores } \\
\text { inequality in years of education (from } \\
\text { isced attainments) }\end{array}$ & $\begin{array}{c}1.631 \\
{[0.815]^{*}} \\
0.849 \\
{[0.370]^{* *}}\end{array}$ & $\begin{array}{c}1.716 \\
{[0.817]^{* *}} \\
0.825 \\
{[0.377]^{* *}}\end{array}$ & $\begin{array}{c}1.073 \\
{[1.029]} \\
1.277 \\
{[1.261]}\end{array}$ & $\begin{array}{c}1.269 \\
{[0.998]} \\
1.544 \\
{[1.272]}\end{array}$ & $\begin{array}{c}1.519 \\
{[0.579]^{\star \star *}} \\
0.73 \\
{[0.843]}\end{array}$ & $\begin{array}{c}1.426 \\
{[0.690]^{* *}} \\
1.314 \\
{[0.916]} \\
\end{array}$ \\
\hline $\begin{array}{l}\text { Observations } \\
\text { R-squared }\end{array}$ & $\begin{array}{c}82 \\
0.84 \\
\end{array}$ & $\begin{array}{c}82 \\
0.85 \\
\end{array}$ & $\begin{array}{c}82 \\
0.84 \\
\end{array}$ & $\begin{array}{c}82 \\
0.83\end{array}$ & $\begin{array}{c}82 \\
0.83\end{array}$ & $\begin{array}{c}82 \\
0.84\end{array}$ \\
\hline $\begin{array}{l}\text { reform on public pre-primary schooling } \\
\text { compulsory education (start age) } \\
\text { compulsory education (end age) } \\
\text { tracking age } \\
\text { introduction of standardised test } \\
\text { reform on school accountability } \\
\text { reform on school teacher autonomy } \\
\text { reform of university access }\end{array}$ & & & $\begin{array}{c}\text { 1st } \\
\text { Gini math } \\
\text { test } \\
-0.102 \\
{[0.020]^{* * *}} \\
-0.066 \\
{[0.012]^{\star * *}} \\
0.01 \\
{[0.002]^{\text {***}}} \\
0.009 \\
{[0.002]^{* * *}} \\
-0.093 \\
{[0.015]^{* * *}} \\
0.015 \\
{[0.027]} \\
0.03 \\
{[0.008]^{* * *}} \\
0.082 \\
{[0.012]^{\star * *}}\end{array}$ & $\begin{array}{c}\text { Ge: } \\
\text { Gini yrs } \\
\text { education } \\
-0.096 \\
{[0.020]^{* * *}} \\
-0.075 \\
{[0.015]^{* * *}} \\
0.009 \\
{[0.002]^{* * *}} \\
0.007 \\
{[0.002]^{* * *}} \\
-0.074 \\
{[0.014]^{* * *}} \\
0.051 \\
{[0.024]^{*}} \\
0.029 \\
{[0.009]^{* * *}} \\
0.038 \\
{[0.011]^{* * *}}\end{array}$ & $\begin{array}{c}\text { 1st s } \\
\text { Gini math } \\
\text { test } \\
-0.102 \\
{[0.021]^{\star * *}} \\
-0.066 \\
{[0.017]^{* * *}} \\
0.01 \\
{[0.002]^{* * *}} \\
0.009 \\
{[0.003]^{* *}} \\
-0.093 \\
{[0.018]^{* * *}} \\
0.015 \\
{[0.032]} \\
0.030 \\
{[0.008]^{* * *}} \\
0.082 \\
{[0.015]^{* * *}}\end{array}$ & $\begin{array}{c}\text { Ge: } \\
\text { Gini yrs } \\
\text { education } \\
-0.096 \\
{[0.072]} \\
-0.075 \\
{[0.041]^{*}} \\
0.009 \\
{[0.005]^{*}} \\
0.007 \\
{[0.055]} \\
-0.074 \\
{[0.055]} \\
0.051 \\
{[0.075]^{*}} \\
0.029 \\
{[0.018]} \\
0.038 \\
{[0.037]}\end{array}$ \\
\hline $\begin{array}{l}\text { R-squared } \\
\text { F test 1st stage [p-value] } \\
\text { Test for overidentifying restrictions } \\
\text { (Sargan for 2SLS, Hansen for GMM) }\end{array}$ & & & $\begin{array}{c}0.94 \\
169.5 \\
{[0.00]} \\
10.17 \\
{[0.11]}\end{array}$ & $\begin{array}{c}0.77 \\
1932.2 \\
{[0.0]} \\
9.51 \\
{[0.14]}\end{array}$ & $\begin{array}{c}0.94 \\
29.29 \\
{[0.0]} \\
10.17 \\
{[0.11]}\end{array}$ & $\begin{array}{c}0.77 \\
1.08 \\
{[0.38]} \\
9.51 \\
{[0.14]}\end{array}$ \\
\hline
\end{tabular}

Standard errors in brackets clustered by country [2sls] or robust against heteroscedasticity [gmm and $1^{\text {st }}$ stage] -

${ }^{*}$ significant at $10 \%$; ${ }^{* *}$ significant at $5 \%$; ${ }^{* *}$ significant at $1 \%$ - constant, gender, age, country, survey and year controls included 
Table 5: Reduced form multipliers computed from table 4: effects of policies on earnings inequality

\begin{tabular}{|c|c|c|c|c|}
\hline & \multicolumn{2}{|c|}{$\begin{array}{l}\text { estimated from } \\
\text { reduced form }\end{array}$} & \multicolumn{2}{|c|}{$\begin{array}{l}\text { computed from columns } \\
\text { (5) and (6) of table } 4\end{array}$} \\
\hline & $\begin{array}{c}\text { Gini index } \\
\text { dependent } \\
\text { employment } \\
\text { earnings }\end{array}$ & $\begin{array}{c}\text { Gini index } \\
\text { on total } \\
\text { labour } \\
\text { earnings }\end{array}$ & $\begin{array}{l}\text { Gini index } \\
\text { dependent } \\
\text { employmen } \\
\text { t earnings }\end{array}$ & $\begin{array}{c}\text { Gini index } \\
\text { on total } \\
\text { labour } \\
\text { earnings }\end{array}$ \\
\hline reform on public pre-primary schooling & $\begin{array}{c}-0.346 \\
{[0.078]^{\star * *}}\end{array}$ & $\begin{array}{c}-0.407 \\
{[0.083]^{* * *}}\end{array}$ & -0.225 & -0.272 \\
\hline compulsory education (start age) & $\begin{array}{c}-0.200 \\
{[0.053]^{* * *}}\end{array}$ & $\begin{array}{c}-0.226 \\
{[0.056]^{\star * *}}\end{array}$ & -0.155 & -0.193 \\
\hline compulsory education (end age) & $\begin{array}{c}0.001 \\
{[0.007]}\end{array}$ & $\begin{array}{c}0.008 \\
{[0.008]}\end{array}$ & 0.022 & 0.026 \\
\hline tracking age & $\begin{array}{l}-0.007 \\
{[0.008]}\end{array}$ & $\begin{array}{l}-0.005 \\
{[0.008]}\end{array}$ & 0.019 & 0.022 \\
\hline introduction of standardised test & $\begin{array}{c}-0.178 \\
{[0.076]^{* *}}\end{array}$ & $\begin{array}{c}-0.232 \\
{[0.088]^{* *}}\end{array}$ & -0.195 & -0.230 \\
\hline reform on school accountability & $\begin{array}{c}0.176 \\
{[0.099]^{*}}\end{array}$ & $\begin{array}{c}0.232 \\
{[0.102]^{\star *}}\end{array}$ & 0.060 & 0.088 \\
\hline reform on school teacher autonomy & $\begin{array}{c}0.100 \\
{[0.031]^{\star * *}}\end{array}$ & $\begin{array}{c}0.125 \\
{[0.032]^{\star * *}}\end{array}$ & 0.067 & 0.081 \\
\hline reform of university access & $\begin{array}{c}0.077 \\
{[0.052]}\end{array}$ & $\begin{array}{c}0.104 \\
{[0.055]^{*}}\end{array}$ & 0.152 & 0.167 \\
\hline $\begin{array}{l}\text { Observations } \\
\text { R-squared }\end{array}$ & $\begin{array}{c}82 \\
0.83\end{array}$ & $\begin{array}{c}82 \\
0.85\end{array}$ & & \\
\hline
\end{tabular}

Standard errors in brackets clustered by country - constant, gender, age, country, survey and year controls included 
Table 6. Distribution of population by background information-PISA 2000 and PIAAC 2012

\begin{tabular}{|l|c|c|c|}
\hline $\begin{array}{l}\text { individual characteristics } \\
\text { (per cent points) }\end{array}$ & $\begin{array}{c}\text { PISA 2000 } \\
\text { (sample } \\
\text { weights) }\end{array}$ & $\begin{array}{c}\text { PIAAC 2012 } \\
\text { Aged 25-29 } \\
\text { (sample } \\
\text { weights) }\end{array}$ & $\begin{array}{c}\text { PIAAC 2012 } \\
\text { Aged 20-34 } \\
\text { (sample } \\
\text { weights) }\end{array}$ \\
\hline male & 49.40 & 50.91 & 50.21 \\
\hline female & 50.60 & 49.09 & 49.79 \\
\hline Either native-born or native-language at home & 98.34 & 91.99 & 91.89 \\
\hline Foreign-born and foreign-language at home & 1.66 & 8.01 & 8.11 \\
\hline both parents less than secondary completed & 29.38 & 15.90 & 16.53 \\
\hline at least one parent with secondary degree & 30.66 & 43.22 & 43.74 \\
\hline at least one parent with college degree & 39.96 & 40.88 & 39.72 \\
\hline books at home (when 14 yrs old): 0-10 & 9.93 & 12.39 & 12.21 \\
\hline books at home (when 14 yrs old): 11-100 & 40.69 & 47.96 & 48.23 \\
\hline books at home (when 14 yrs old): 101-500 & 37.63 & 32.06 & 32.39 \\
\hline books at home (when 14 yrs old): $>500$ & 11.74 & 7.60 & 7.18 \\
\hline
\end{tabular}


Table 7. Determinants of (log) earnings - population aged 25-29 - PIAAC 2012

\begin{tabular}{|c|c|c|c|c|c|c|}
\hline & 1 & 2 & 3 & 4 & 5 & 6 \\
\hline & OLS & OLS & OLS & oprobit & oprobit & oprobit \\
\hline \multirow[t]{2}{*}{ adult competences } & $0.001^{* *}$ & & $0.001^{* * *}$ & $0.005^{* \star *}$ & & $0.004^{* * *}$ \\
\hline & {$[0.000]$} & & {$[0.000]$} & {$[0.001]$} & & {$[0.000]$} \\
\hline \multirow{2}{*}{$\begin{array}{l}\text { young competences (from PISA cells' } \\
\text { means) }\end{array}$} & & 0.001 & 0.000 & & $0.003^{* \star *}$ & $0.002^{\star \star *}$ \\
\hline & & {$[0.001]$} & {$[0.001]$} & & {$[0.000]$} & {$[0.000]$} \\
\hline \multirow{2}{*}{ Years of education } & $0.036^{\star \star *}$ & $0.041^{* \star *}$ & $0.036^{\star \star \star}$ & $0.099^{\star \star \star}$ & $0.117^{\star \star \star *}$ & $0.093^{\star \star *}$ \\
\hline & {$[0.008]$} & {$[0.008]$} & {$[0.010]$} & {$[0.022]$} & {$[0.030]$} & {$[0.023]$} \\
\hline \multirow[t]{2}{*}{ female } & $-0.124^{\star \star *}$ & $-0.123^{* \star *}$ & $-0.116^{* *}$ & $-0.287^{\star \star \star}$ & $-0.299^{* * *}$ & $-0.259^{* \star *}$ \\
\hline & {$[0.035]$} & {$[0.038]$} & {$[0.039]$} & {$[0.068]$} & {$[0.049]$} & {$[0.062]$} \\
\hline \multirow[t]{2}{*}{ age } & -0.203 & -0.255 & -0.248 & 0.769 & 0.586 & 0.651 \\
\hline & {$[0.580]$} & [0.599] & {$[0.596]$} & [0.691] & [0.692] & [0.718] \\
\hline \multirow[t]{2}{*}{$\mathrm{age}^{2}$} & 0.004 & 0.005 & 0.005 & -0.013 & -0.01 & -0.011 \\
\hline & {$[0.011]$} & {$[0.011]$} & {$[0.011]$} & {$[0.013]$} & {$[0.013]$} & [0.013] \\
\hline Observations & 5605 & 5485 & 5485 & 8345 & 8206 & 8206 \\
\hline Countries & 15 & 15 & 15 & 20 & 20 & 20 \\
\hline$R^{2}$-Pseudo $R^{2}$ & 0.92 & 0.919 & 0.92 & 0.04 & 0.04 & 0.04 \\
\hline
\end{tabular}


Table 8. Inequality in education and earnings - population aged 25-29 and 20-65PIAAC 2012

\begin{tabular}{|c|c|c|c|c|c|c|}
\hline & 1 & 2 & 3 & 4 & 5 & 6 \\
\hline \multirow[t]{2}{*}{ VARIABLES } & $\begin{array}{l}\text { Gini hourly } \\
\text { wage decile }\end{array}$ & $\begin{array}{l}\text { Gini hourly } \\
\text { wage decile }\end{array}$ & $\begin{array}{l}\text { Gini hourly } \\
\text { wage decile }\end{array}$ & $\begin{array}{l}\text { Gini hourly } \\
\text { wage decile }\end{array}$ & $\begin{array}{l}\text { Gini hourly } \\
\text { wage decile }\end{array}$ & $\begin{array}{c}\text { Gini hourly } \\
\text { wage decile }\end{array}$ \\
\hline & \multicolumn{3}{|c|}{ aged 25-29 } & \multicolumn{3}{|c|}{ aged $20-65$} \\
\hline \multirow{2}{*}{ Gini index years of education } & $0.487^{\star *}$ & $0.657^{* * *}$ & $0.484^{* *}$ & -0.209 & -0.007 & -0.209 \\
\hline & {$[0.227]$} & [0.212] & {$[0.230]$} & {$[0.177]$} & [0.175] & {$[0.177]$} \\
\hline \multirow{2}{*}{$\begin{array}{l}\text { Gini index adult competences - } \\
\text { PIAAC } 2012\end{array}$} & $0.676^{* *}$ & & $0.716^{* *}$ & $1.074^{* * *}$ & & $0.981^{* * *}$ \\
\hline & {$[0.250]$} & & [0.295] & {$[0.277]$} & & [0.289] \\
\hline \multirow{2}{*}{$\begin{array}{l}\text { Gini index youth competences } \\
\text { (imputed) - PISA } 2000\end{array}$} & & 0.395 & -0.139 & & $1.025^{* *}$ & 0.595 \\
\hline & & [0.370] & [0.443] & & {$[0.448]$} & [0.458] \\
\hline \multirow{2}{*}{ female population share } & $0.033^{* * *}$ & $0.032^{* * *}$ & $0.033^{* * *}$ & $0.050^{* * *}$ & $0.046^{* * *}$ & $0.049^{* * *}$ \\
\hline & {$[0.007]$} & [0.008] & [0.008] & {$[0.004]$} & {$[0.004]$} & {$[0.004]$} \\
\hline Observations & 40 & 40 & 40 & 360 & 360 & 360 \\
\hline Countries & 20 & 20 & 20 & 20 & 20 & 20 \\
\hline $\mathrm{R}^{2}$ & 0.467 & 0.384 & 0.468 & 0.65 & 0.639 & 0.652 \\
\hline
\end{tabular}

Robust standard errors in brackets ${ }^{* * *} p<0.01,{ }^{* *} p<0.05,{ }^{*} p<0.1$ - constant, country controls included columns 4 to 6 also include birth cohort controls 
Figure 1: Inequality in competences, years of schooling, gross labour earnings (dependent employment and total employment - From SILC2009)
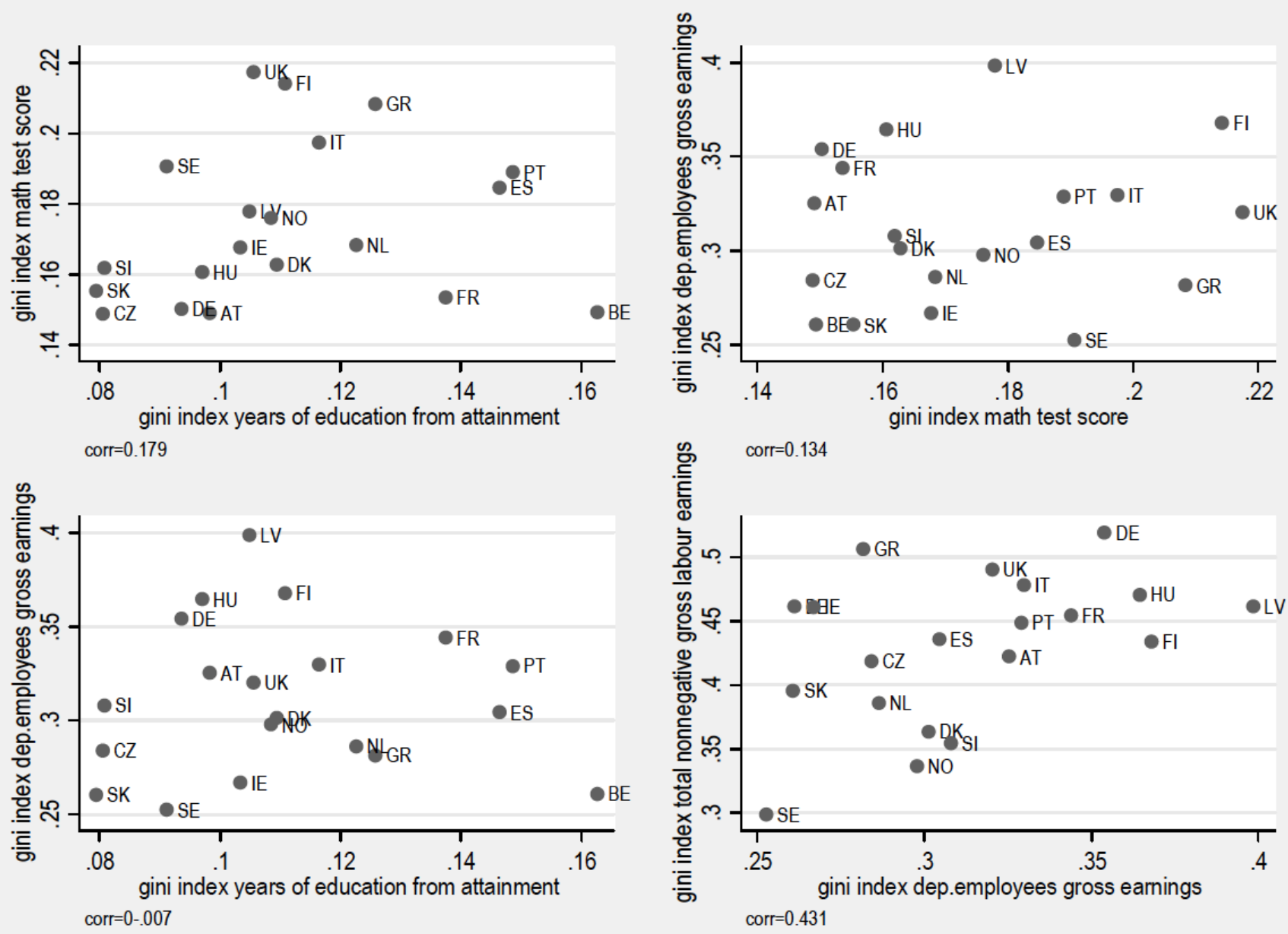
Figure 2: Earnings inequality impact of educational reforms

\section{Impact on Gini index on dependent employment earnings}

of one standard deviation increase in reform variables

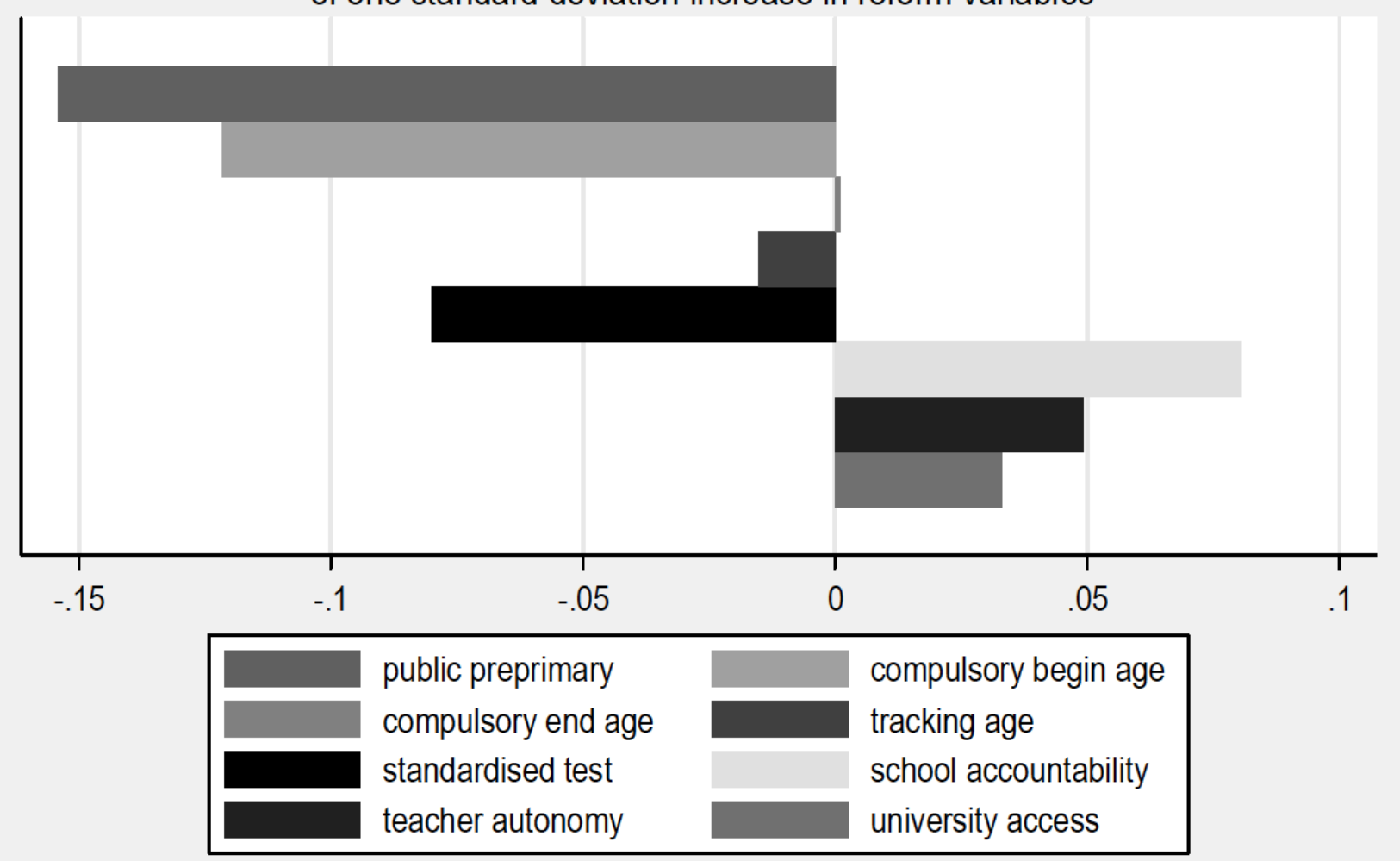


Figure 3: Inequality in current and past competences, years of schooling and gross labour earnings
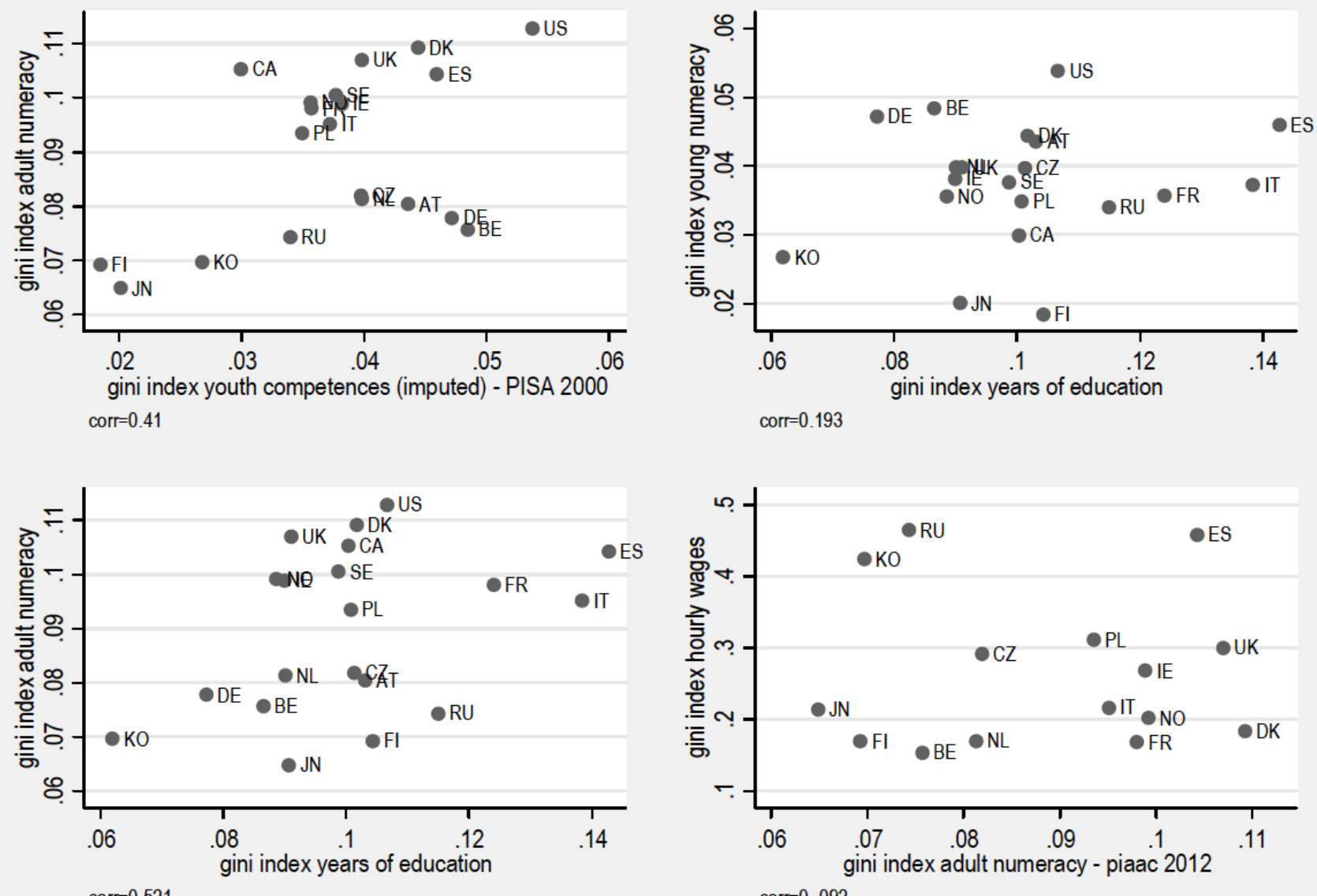

corr $=0.521$

corr $=0-.092$ 
Table A1 - Inequality in earnings and educational attainment - averages across gender and age cohorts

$1^{\text {st }}$ number: Gini index on gross total labour earnings of employed -

$2^{\text {nd }}$ number: Gini index on years of education of the same population (from maximal educational attainment) -

$3^{\text {rd }}$ number: Gini index on math test score -

$4^{\text {th }}$ number: individuals with positive earnings

$5^{\text {th }}$ number: observations available in the sample

\begin{tabular}{|c|c|c|c|c|}
\hline & & irth ye & & \\
\hline & 1950 & 1966 & 1981 & Total \\
\hline Austria & & & 0.32 & 0.32 \\
\hline & & & 0.10 & 0.10 \\
\hline & & & 0.15 & 0.15 \\
\hline & & & 134 & 134 \\
\hline & & & 2 & 2 \\
\hline Belgium & 0.32 & 0.25 & 0.21 & 0.27 \\
\hline & 0.15 & 0.12 & 0.10 & 0.13 \\
\hline & 0.17 & 0.15 & 0.12 & 0.15 \\
\hline & 202 & 282 & 136 & 620 \\
\hline & 4 & 4 & 2 & 10 \\
\hline Czech Republic & & & 0.30 & 0.30 \\
\hline & & & 0.08 & 0.08 \\
\hline & & & 0.15 & 0.15 \\
\hline & & & 188 & 188 \\
\hline & & & 2 & 2 \\
\hline Denmark & & & 0.30 & 0.30 \\
\hline & & & 0.11 & 0.11 \\
\hline & & & 0.16 & 0.16 \\
\hline & & & 97 & 97 \\
\hline & & & 2 & 2 \\
\hline Finland & 0.37 & 0.35 & & 0.36 \\
\hline & 0.12 & 0.10 & & 0.11 \\
\hline & 0.21 & 0.22 & & 0.21 \\
\hline & 363 & 361 & & 724 \\
\hline & 2 & 2 & & 4 \\
\hline France & 0.41 & 0.33 & 0.26 & 0.35 \\
\hline & 0.17 & 0.12 & 0.10 & 0.14 \\
\hline & 0.18 & 0.15 & 0.14 & 0.16 \\
\hline & 456 & 545 & 246 & 1247 \\
\hline & 4 & 4 & 2 & 10 \\
\hline Germany & 0.35 & & 0.36 & 0.35 \\
\hline & 0.12 & & 0.09 & 0.11 \\
\hline & 0.14 & & 0.16 & 0.15 \\
\hline & 638 & & 185 & 823 \\
\hline & 4 & & 2 & 6 \\
\hline Greece & & & 0.31 & 0.31 \\
\hline & & & 0.11 & 0.11 \\
\hline & & & 0.21 & 0.21 \\
\hline & & & 168 & 168 \\
\hline & & & 2 & 2 \\
\hline Hungary & & 0.35 & 0.37 & 0.36 \\
\hline & & 0.09 & 0.09 & 0.09 \\
\hline & & 0.16 & 0.16 & 0.16 \\
\hline & & 266 & 234 & 500 \\
\hline & & 2 & 2 & 4 \\
\hline Ireland & & & 0.26 & 0.26 \\
\hline & & & 0.10 & 0.10 \\
\hline & & & 0.17 & 0.17 \\
\hline
\end{tabular}




\begin{tabular}{|c|c|c|c|c|}
\hline & & & 85 & 85 \\
\hline & & & 2 & 2 \\
\hline
\end{tabular}

\begin{tabular}{|c|c|c|c|c|}
\hline Italy & & & 0.33 & 0.33 \\
\hline & & & 0.11 & 0.11 \\
\hline & & & 0.20 & 0.20 \\
\hline & & & 421 & 421 \\
\hline & & & 2 & 2 \\
\hline Latvia & & & 0.39 & 0.39 \\
\hline & & & 0.10 & 0.10 \\
\hline & & & 0.18 & 0.18 \\
\hline & & & 134 & 134 \\
\hline & & & 2 & 2 \\
\hline Netherlands & 0.32 & 0.28 & 0.22 & 0.28 \\
\hline & 0.12 & 0.11 & 0.10 & 0.11 \\
\hline & 0.18 & 0.18 & 0.14 & 0.17 \\
\hline & 406 & 482 & 196 & 1084 \\
\hline & 4 & 4 & 2 & 10 \\
\hline Norway & & & 0.30 & 0.30 \\
\hline & & & 0.11 & 0.11 \\
\hline & & & 0.18 & 0.18 \\
\hline & & & 107 & 107 \\
\hline & & & 2 & 2 \\
\hline Portugal & & & 0.33 & 0.33 \\
\hline & & & 0.15 & 0.15 \\
\hline & & & 0.19 & 0.19 \\
\hline & & & 106 & 106 \\
\hline & & & 2 & 2 \\
\hline Slovak Republic & & & 0.26 & 0.26 \\
\hline & & & 0.08 & 0.08 \\
\hline & & & 0.16 & 0.16 \\
\hline & & & 198 & 198 \\
\hline & & & 2 & 2 \\
\hline Slovenia & & & 0.30 & 0.30 \\
\hline & & & 0.08 & 0.08 \\
\hline & & & 0.16 & 0.16 \\
\hline & & & 420 & 420 \\
\hline & & & 2 & 2 \\
\hline Spain & & & 0.31 & 0.31 \\
\hline & & & 0.14 & 0.14 \\
\hline & & & 0.18 & 0.18 \\
\hline & & & 361 & 361 \\
\hline & & & 2 & 2 \\
\hline Sweden & & 0.23 & 0.28 & 0.25 \\
\hline & & 0.09 & 0.09 & 0.09 \\
\hline & & 0.22 & 0.16 & 0.19 \\
\hline & & 260 & 155 & 415 \\
\hline & & 2 & 2 & 4 \\
\hline United Kingdom & 0.37 & 0.36 & 0.29 & 0.35 \\
\hline & 0.14 & 0.13 & 0.09 & 0.13 \\
\hline & 0.23 & 0.24 & 0.18 & 0.22 \\
\hline & 387 & 554 & 130 & 1071 \\
\hline & 4 & 4 & 2 & 10 \\
\hline Total & 0.35 & 0.3 & 0.3 & 0.32 \\
\hline & 0.14 & 0.11 & 0.1 & 0.11 \\
\hline & 0.18 & 0.19 & 0.17 & 0.18 \\
\hline & 2452 & 2750 & 3701 & 8903 \\
\hline & 22 & 22 & 38 & 82 \\
\hline
\end{tabular}


Table A2 - Areas of educational reform (from Braga et al. 2013)

\begin{tabular}{|c|c|c|}
\hline area of reform & $\begin{array}{l}\text { expected impact on schooling } \\
\text { inequality }\end{array}$ & $\begin{array}{l}\text { available information } \\
\text { on reforming activity }\end{array}$ \\
\hline $\begin{array}{l}\text { pre-primary } \\
\text { education }\end{array}$ & $\begin{array}{l}\text { reduction (through increased educational } \\
\text { attainment of students from disadvantaged } \\
\text { background) }\end{array}$ & $\begin{array}{ll}\checkmark & \text { extending access to (public } \\
\text { preprimary education } \\
\checkmark \\
\text { making preprimary education } \\
\text { compulsory } \\
\checkmark \quad \begin{array}{l}\text { raising training requirements for } \\
\text { preprimary teachers }\end{array} \\
\end{array}$ \\
\hline $\begin{array}{l}\text { expansion of } \\
\text { compulsory } \\
\text { education }\end{array}$ & $\begin{array}{l}\text { reduction (through increased educational } \\
\text { attainment of students from disadvantaged } \\
\text { background) }\end{array}$ & $\begin{array}{ll}\checkmark & \text { compulsory education (start age) } \\
\checkmark & \text { compulsory education (end age) }\end{array}$ \\
\hline school tracking & $\begin{array}{l}\text { ambiguous (vocational tracks have shorter } \\
\text { duration, prevent academic enrolment but } \\
\text { have lower drop-out rates) }\end{array}$ & $\checkmark \quad$ raising tracking age \\
\hline school autonomy & $\begin{array}{l}\text { ambiguous (adaptability to social } \\
\text { environment, increased competition in } \\
\text { presence of centralised control) }\end{array}$ & $\begin{array}{ll}\checkmark & \text { national testing for other purposes } \\
\text { than career advancement } \\
\checkmark \quad \text { teacher autonomy in designing } \\
\text { curricula }\end{array}$ \\
\hline school accountability & $\begin{array}{l}\text { increase (school differentiation, screening } \\
\text { and sorting of students) }\end{array}$ & $\begin{array}{ll}\checkmark & \text { national testing for career } \\
& \text { advancement (ISCED } 1 \text { and 2) }\end{array}$ \\
\hline teacher qualification & $\begin{array}{l}\text { ambiguous (better quality benefits students } \\
\text { from poorer backgrounds but allows fro } \\
\text { greater differentiation) }\end{array}$ & $\begin{array}{ll}\checkmark & \text { strengthening teacher training } \\
\text { requirements for primary school } \\
\text { teachers } \\
\checkmark \quad \text { strengthening teacher training } \\
\text { requirements for secondary school } \\
\text { teachers }\end{array}$ \\
\hline $\begin{array}{l}\text { university autonomy } \\
\text { and selectivity }\end{array}$ & $\begin{array}{l}\text { increase (increased signalling value of } \\
\text { tertiary education requires a more } \\
\text { intensive selectivity in university } \\
\text { admissions) }\end{array}$ & $\begin{array}{ll}\checkmark & \text { selectivity in admissions } \\
\checkmark & \text { financial support to student } \\
\checkmark & \text { size of grant/loan component/interest } \\
& \text { rates } \\
\checkmark & \text { university autonomy (budget, } \\
& \text { recruitment, organization, logistics, } \\
& \text { course design, self-evaluation, } \\
& \text { planning) }\end{array}$ \\
\hline
\end{tabular}


Table A3 - Sample size of PISA 2000 and PIAAC 2012 for countries participating to both surveys

\begin{tabular}{|c|c|c|c|c|c|c|}
\hline country & $\begin{array}{l}\text { PISA } \\
2000\end{array}$ & $\begin{array}{c}\text { PIAAC } \\
2012 \\
\text { Aged 16- } \\
19\end{array}$ & $\begin{array}{c}\text { PIAAC } \\
2012 \\
\text { Aged 20- } \\
24\end{array}$ & $\begin{array}{c}\text { PIAAC } \\
2012 \\
\text { Aged 25- } \\
29\end{array}$ & $\begin{array}{c}\text { PIAAC } \\
2012 \\
\text { Aged 30- } \\
34\end{array}$ & $\begin{array}{c}\text { PIAAC } \\
2012 \\
\text { Aged 35- } \\
39\end{array}$ \\
\hline AUSTRIA & 2401 & 424 & 462 & 465 & 464 & 497 \\
\hline BELGIUM & 3453 & 432 & 478 & 398 & 442 & 442 \\
\hline CANADA & 16010 & 2146 & 2320 & 2084 & 2370 & 2530 \\
\hline CZECH REPUBLIC & 3002 & 716 & 747 & 702 & 617 & 593 \\
\hline DENMARK & 2247 & 514 & 542 & 452 & 566 & 614 \\
\hline FINLAND & 2529 & 409 & 462 & 474 & 534 & 458 \\
\hline FRANCE & 2371 & 493 & 517 & 536 & 555 & 599 \\
\hline GERMANY & 2498 & 493 & 542 & 482 & 471 & 448 \\
\hline IRELAND & 2071 & 332 & 409 & 563 & 795 & 803 \\
\hline ITALY & 2680 & 222 & 301 & 339 & 439 & 588 \\
\hline JAPAN & 2816 & 356 & 393 & 405 & 492 & 626 \\
\hline KOREA, REPUBLIC OF & 2759 & 569 & 496 & 600 & 653 & 749 \\
\hline NETHERLANDS & 1308 & 423 & 456 & 377 & 406 & 460 \\
\hline NORWAY & 2123 & 480 & 468 & 423 & 490 & 517 \\
\hline POLAND & 1749 & 1052 & 3377 & 1643 & 451 & 447 \\
\hline RUSSIAN FEDERATION & 3573 & 423 & 762 & 463 & 324 & 250 \\
\hline SPAIN & 3184 & 457 & 512 & 521 & 627 & 714 \\
\hline SWEDEN & 2362 & 372 & 443 & 389 & 402 & 413 \\
\hline UNITED KINGDOM & 4748 & 456 & 652 & 758 & 942 & 917 \\
\hline UNITED STATES & 1842 & 343 & 467 & 516 & 502 & 464 \\
\hline Total & 65726 & 11112 & 14806 & 12590 & 12542 & 13129 \\
\hline
\end{tabular}


Figure A1 - Country averages of educational reform measures with inclusive orientation (from Braga et al. 2013)

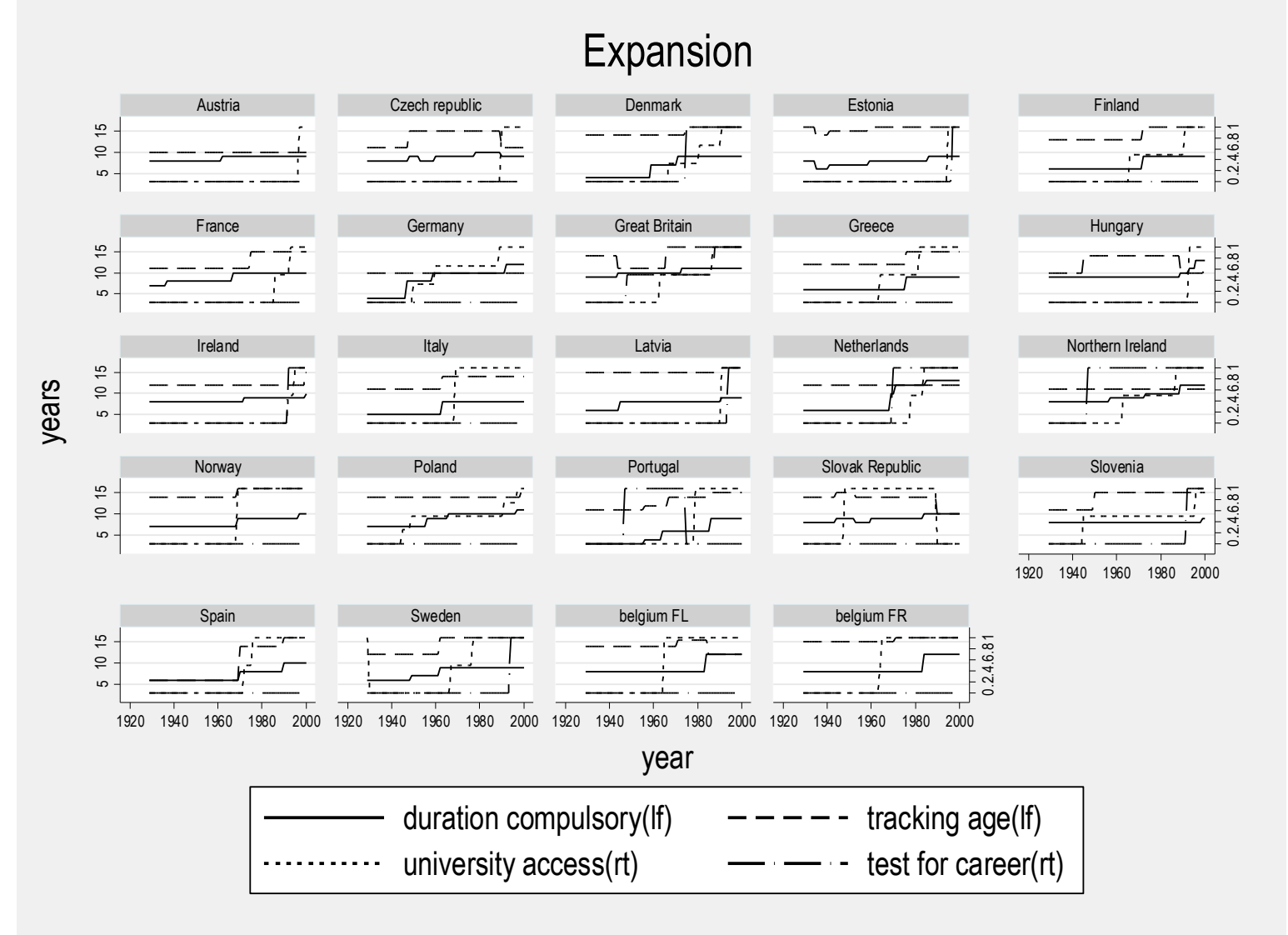

